\title{
MAP OF THE NEEDS OF UMSU STUDENTS ON AL-ISLAM AND MUHAMMADIYAH CURRICULUM
}

\author{
${ }^{1}$ Nurzannah, ${ }^{2}$ Mahmud Yunus Daulay, ${ }^{3}$ Nurman Ginting \\ University of Muhammadiyah Sumatera Utara, Indonesia \\ nurzannah@umsu.ac.id,myunusdaulay@umsu.ac.id,nurmanginting@umsu.ac.id
}

Received: 01-09-2021

Revised: 30-10-2021

Accepted: 14-11-2021

\begin{abstract}
The purpose of this study was to produce a map of the needs of UMSU students for Al-Islam and Kemuhammadiyahan (AIK) courses. This type of research is qualitative research that uses survey techniques. Data collection was carried out by questionnaires and interviews. The data analysis techniques used are; describe the data, analyze, and interpret, and conclude. The results showed that the map of the needs of UMSU students for AIK courses were: 1) Students with religious understanding backgrounds other than Muhammadiyah (92 people/76.8\%) of the 396 respondents stated that the provision of Worship courses, in particular, not through doctrine and coercion, but must pay attention to the background of the religious understanding they already profess. 2) Non-Muslim students generally state that Worship courses are not taught in the form of doctrine as given to Muslim students but must consider their religious background, and AIK courses should be taught in the form of Islamology courses, or the like. 3) Students from Muhammadiyah schools tend to want the provision of AIK courses to be packaged with other programs. Or by combining face-to-face in class with more interesting programs, not just face-to-face routines. 4) Most of the respondents stated that learning strategies and methods need to be adapted to the needs of students
\end{abstract}

Keywords: Needs Map, UMSU Students, AIK Curriculum

\begin{abstract}
Abstrak
Tujuan penelitian ini adalah untuk menghasilkan peta kebutuban mahasiswa UMSU terbadap mata kuliah Al-Islam dan Kemubammadiyahan (AIK). Jenis penelitian ini adalah penelitian kualitatif yang menggunakan teknik survey. Pengumpulan data dilakukan dengan angket, dan wawancara. Teknik. analisis data yang digunakan adalah; mendeskripsikan data, menganalisis, dan menginterpretasikan, serta menyimpulkan. Hasil penelitian menunjukkean bahwa peta kebutuhan mahasiswa UMSU terhadap mata kuliah AIK adalab: 1) Mahasiswa yang latar belakang pemahaman keagamaan selain Mubammadiyah (92 orang/76.8\%) dari 396 responden, menyatakan agar pemberian mata kuliah Ibadah khususnya, tidak melalui doktrin dan pemaksaan, tetapi harus memperhatikan latar belakang pemahaman agama yang sudah mereka anut. 2) Mabasiswa non-muslim umumnya menyatakan babwa mata kuliah Ibadah tidak diajarkan dalam bentuk doktrin sebagaimana yang diberikan kepada mahasiswa Muslim, akan tetapi harus mempertimbangkan latar belakang agama mereka, dan sebaiknya mata kuliah AIK diajarkan dalam bentuk mata kuliah Islamologi, atau sejenisnya. 3) Mahasiswa yang berasal dari Sekolah Mubammadiyah cenderung menginginkan agar pemberian mata kuliah AIK di kemas dengan program lain. Atau dengan memadukan antara tatap muka di kelas dengan program-program yang lebih menarik, tidak sekedar rutinitas tatap muka. 4)
\end{abstract}


Sebagian besar responden menyatakan babwa strategi dan metode pembelajaran perlu disesuaikan dengan kebutuban mahasiswa

Kata Kunci : Peta Kebutuhan, Mahasiswa UMSU, Kurikulum AIK

\section{INTRODUCTION}

Al-Islam and Kemuhammadiyahan (AIK) courses are subjects that must be studied by all students studying at every Muhammadiyah and Aisyiyah College (PTMA ${ }^{1}$ ), including the Muhammadiyah University of North Sumatra. Because this course is a hallmark for every Muhammadiyah College. Implicitly, giving this AIK course is one of Muhammadiyah's da'wah strategies in realizing Muhammadiyah's goals and ideals.

AIK courses at various PTMAs should have been arranged according to university implementation guidelines. Because AIK has a big role in instilling the values of life to students. Values education is not just a special program taught through courses but includes the entire educational process. Al-Islam and Kemuhammadiyahan are wisdom that should be achieved in every educational organization within Mubammadiyah for the formation of human learners who are pious, have a noble character, progress, and excel in science and technology as the embodiment of tajdid da'wah amar makruf nabi munkar in accordance with the mandate contained in the Decision of the Muhammadiyah Congress 46 on the Revitalization of Mubammadiyah Education. ${ }^{2}$

This vision indirectly obliges all Muhammadiyah Universities to improve quality in various aspects including AIK Education as one of Mubammadiyab's missions in da'wah. Carrying out da'wah is an effort that is not simple, and must be carried out with the right strategy so that the mission and goals of $d a^{\prime} w a b$ are achieved effectively and efficiently. Likewise, the provision of AIK courses to students at the Muhammadiyah University of North Sumatra (UMSU) ${ }^{3}$, should not only be given as mere knowledge, but must be well organized so that it functions as an effective propaganda medium.

Based on several research results on AIK courses, it turns out that there are still many problems faced by UMSU, including those carried out by Pinem, and Amini explained that AIK learning at UMSU is still dominant using conventional methods. Nurzannah researching the religious behavior of UMSU students found that the scores for the faith and social aspects of students were high, but the attitude and worship aspects were low. ${ }^{4}$

Based on the results of observations and experiences both when he was a student, and when he became a lecturer, the AIK courses at UMSU seemed to be carried out in a modest manner. In fact, it can be seen contextually that the more varied the background of students studying at UMSU, the implementation of AIK courses does not have a significant change. This causes AIK courses to be given: 1) Only focusing on the knowledge aspect, paying less

\footnotetext{
${ }^{1}$ Perguruan Tinggi Muhammadiyah dan Aisyiyah

2PP. Muhammadiyah, T. P. P. A.-I. dan K. M. P. T. P. Buku Pedoman Pendidikan Al-Islam dan Kemuhammadiyahan Perguruan Tinggi Muhammadiyah (Yogyakarta: Majelis Pendidikan Tinggi Muhammadiyah PP Muhammadiyah, 2013), 11-12.

${ }^{3}$ Universitas Muhammadiyah Sumatra Utara

${ }^{4}$ Nurzannah, Analisis Perilaku Keagamaan Mahasiswa Universitas Muhammadiyah Sumatera Utara (Studi Kasus Pada Mahasiswa Fisipol Semester V TA. 2016-2017), Jurnal HIJRI - Jurnal Manajemen Pendidikan Dan Keislaman, 6(1), 2017, 150-165.
} 
attention to affective and personality aspects; 2) More dense content than meaning; 3) Students have not received learning services according to their needs; 4) There is no specific approach for non-Muslim students.

In addition, UMSU students have very varied profiles. First, the background of high school education from Muhammadiyah educational institutions, mostly from nonMuhammadiyah educational institutions. Second, the background of the family organization which also influences religious understanding. There are also those who come from nonMuslim ideologies and beliefs.

The various problems above really need structuring, namely by mapping the needs of UMSU students towards Al-Islam and Kemuhammadiyahan courses. The formulation of the problem discussed in this study is "How is the map of the needs of UMSU students for AIK courses"? The purpose of this study was to produce a map of the needs of UMSU students for AIK . courses

\section{METHOD}

This research was conducted at the Muhammadiyah University of North Sumatra. This type of research is descriptive qualitative. The method used in this research is the survey method. Data collection techniques using questionnaires, and interviews. Questionnaires were used to collect data on the map of the needs of UMSU students for AIK courses.

The number of questionnaire items made was 20 items. However, after going through this validation, only 18 items were valid, consisting of six classifications of questions. The first classification is 3 items that are intended only for non-Muslim students, the second classification is 6 items for Muslim students only, the third classification is only 1 item is intended for Muslim students with non-Muhammadiyah educational backgrounds, the fourth classification 2 items is aimed at students with Muhammadiyah educational backgrounds, and the fifth classification of 6 questionnaire items answered for all students without exception. Questionnaires were distributed using Google Forms to all Faculties and Study Programs at UMSU, minus the Faculty of Medicine and Postgraduate. Questionnaires were distributed for 15 days. Interviews are used to explore data that will strengthen the data obtained through questionnaires. The data analysis technique was carried out with the following steps: Data reduction, data presentation, data verification and conclusion drawing.

\section{RESULTS AND DISCUSSION}

At the initial stage (before the research took place), the research team made preparations by determining the research sample. The results of the team's discussion determined that, because the student population of UMSU was large, namely students in the 2nd semester of elementary school. Semester 6, and the questionnaire was collected using google form, then the sample was determined by means of snow ball sampling. This was done, because the respondents who were recruited and expected to fill out a questionnaire through the google form were uncertain.

After the questionnaires were distributed for 15 days, the questionnaires were collected from 447 respondents. After verification of all incoming questionnaires, it was found that several respondents filled out 2 and 3 times. Therefore, the team sorted the questionnaire. 
Finally obtained as many as 438 respondents. Of the 438 questionnaires referred to, 32 questionnaires were found that could not be used, because they were deemed not to meet the requirements for filling out the questionnaire (defective data). In the end, the sample used in this study amounted to 406 samples, 10 of whom were non-Muslims, and 396 were Muslims. The data from the 406 samples can be classified in the table below.

Tabel. 1 Respondent Classification

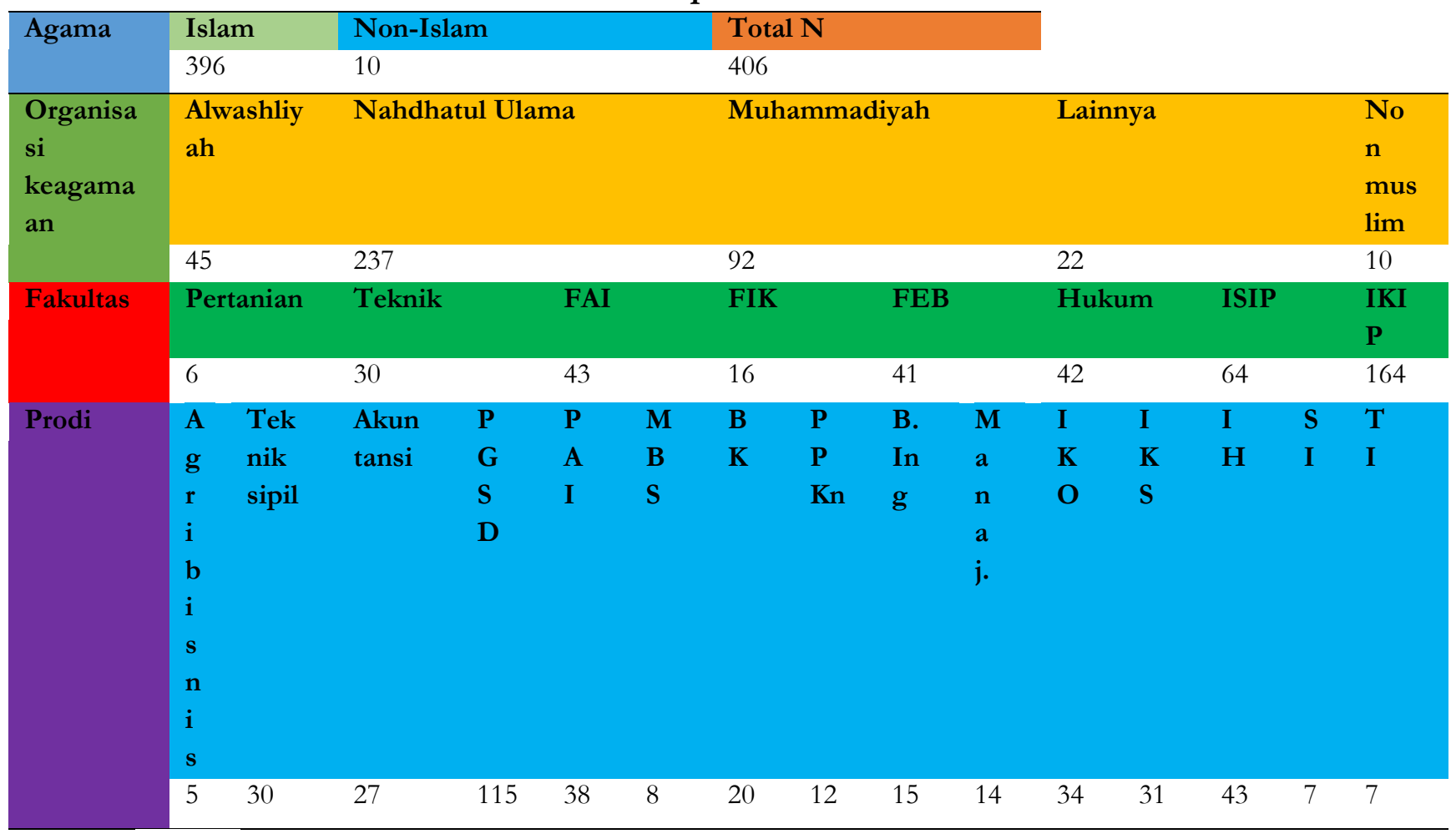

\section{Keterangan N (Jumlah) responden untuk semua tabel:}

$\mathrm{N}$ for all students 406 respondents

$\mathrm{N}$ for non-Muslim students 10 respondents

$\mathrm{N}$ for Muslim students 396 respondents

The data contained in the table above as a whole shows that the respondents who filled out the questionnaire had represented the 8 faculties in question. Meanwhile, the representation of Study Programs reached 15 Study Programs out of 29 Study Programs throughout UMSU (51.71\%). This means that the data recruitment from respondents is representative.

Furthermore, the urgent data related to this research is about the organization/religious ideology adopted by the respondents. This is because this indicator of religious understanding will map students' needs for this AIK course. The table above shows that it turns out that UMSU students are dominated by non-Muhammadiyah students. If the ranking is carried out, then students with Nahdlatul Ulama (NU) backgrounds are 237 people $(58.4 \%)$ of all 406 respondents in the first rank. There were 92 students with a background in Muhammadiyah organizations (22.6\%), in second place. Meanwhile, 45 students (11.1\%) with 
backgrounds in the mass organization Al-Washliyah were in the third place, 22 students from other organizations/faculty backgrounds (5.4\%), in fourth place, and 10 Christians who were Christian. people (2.5\%). The conclusion is that of the 406 respondents, only 92 students have a background in the organization and religious understanding of Muhammadiyah.

The results of this study will be explained according to the category of questionnaire items distributed. Although in general the results of this study can be read through the data listed in the following tables, it would be better if it was explained in detail, which was strengthened by the results of interviews with respondents. Furthermore, the twenty-six questionnaire items above are discussed according to the categories and types of respondents' needs. The needs that have been categorized include 1) AIK learning strategies for nonMuslims, 2) appropriate learning strategies and methods for Muslim students in general, 3) learning strategies or models for non-Muhammadiyah students, and 4) learning strategies and models for students who come from Muhammadiyah schools.

Tabel. 2 The Need for AIK Learning Strategies and Methods for Non-Muslim Students

\begin{tabular}{|c|c|c|c|c|}
\hline $\begin{array}{l}\text { No. } \\
\text { Item }\end{array}$ & Questions & Answers & Frequency & $\mathbf{N}$ \\
\hline \multirow[t]{3}{*}{1} & \multirow{3}{*}{$\begin{array}{l}\text { For non-Muslim students, do you } \\
\text { feel disturbed when you learn about } \\
\text { aqidah-akhlak, and Islamic worship? }\end{array}$} & 1. Yes & 1 & \multirow[b]{3}{*}{10} \\
\hline & & 2. Sometimes & 1 & \\
\hline & & 3. No & 8 & \\
\hline \multirow[t]{4}{*}{2} & \multirow{4}{*}{$\begin{array}{l}\text { For non-Muslim students, if you } \\
\text { feel disturbed, what should the } \\
\text { university do? }\end{array}$} & $\begin{array}{l}\text { 1. Do not teach in the } \\
\text { form of doctrine }\end{array}$ & 2 & \multirow{4}{*}{10} \\
\hline & & $\begin{array}{l}\text { 2. Not in the way UMSU } \\
\text { wanted }\end{array}$ & 0 & \\
\hline & & $\begin{array}{l}\text { 3. Teach according to } \\
\text { religious background. }\end{array}$ & 4 & \\
\hline & & 4. All right & 4 & \\
\hline \multirow[t]{3}{*}{3} & $\begin{array}{l}\text { For non-Muslim students. Because } 1 \\
\text { you study at UMSU, you must take }\end{array}$ & $\begin{array}{l}\text { 1. Keep Studying these } 4 \\
\text { courses like so far }\end{array}$ & 1 & \\
\hline & $\begin{array}{lrr}\text { all courses in Al-Islam } & \text { and } 2 \\
\text { Kemuhammadiyahan for } & 4\end{array}$ & $\begin{array}{l}\text { 2. Study it in the form of } \\
\text { the "Islamology" course }\end{array}$ & 4 & \\
\hline & $\begin{array}{l}\text { semesters. However, we offer the } 3 \\
\text { following alternatives: }\end{array}$ & $\begin{array}{l}\text { 3. Studying } 4 \text { courses, not } \\
\text { in the form of doctrine. }\end{array}$ & 5 & 10 \\
\hline
\end{tabular}

Questionnaire items numbered 1 to 3 are specific questions for non-Muslim students. After being analyzed, it can be seen that studying Aqidah/Akhlak and worship courses for non-Muslim students does not bother them, or it can be said that there is no problem. Because, out of 10 non-Muslim respondents, eight of them said they were not disturbed. However, it is inversely proportional to the answers stated in items 2 and 3.

Item 1 answered disturbed and sometimes, each answered by 1 respondent. This data is indeed interesting, especially after confirmation through an interview with one of the respondents stated that he did not mind learning the material for aqidah and worship, because 
there was no coercion. The coercion meant by the student was not being forced to convert to Islam, but simply studying. In addition, their parents often remind them that they only think of it as knowledge and keep studying their own religion ${ }^{5}$. The same thing was revealed by NM. For him, taking AIK courses is not a problem, because he only participates in learning. ${ }^{6}$

In items 2 and 3, in principle the questions asked are the same. The point is that AIK courses must be studied by non-Muslim students, with alternative learning strategies. One $(10 \%)$ respondent stated that he continued to study the 4 courses as he had been so far, 4 people $(40 \%)$ stated that they studied it in the form of "Islamology" courses, and 5 people (50\%) stated that the Aqeedah and Worship courses should not be taught in doctrinal form.

This proves that basically, although initially non-Muslim respondents stated that there was no problem studying the two subjects, on the other hand, they wanted to be taught according to their religion. The non-Muslim respondent's expression according to the research team is something natural, because for someone who has adhered to a belief or an ideology from childhood to adulthood, if there is no intention to convert to religion, of course he does not want to learn another religion. As stated by Prasetyo, ideology (belief) is totalitarian. With this totalitarian nature, ideology (religion, belief) demands absolutely (no bargaining) for humans to live and behave according to what has been determined by the ideology. ${ }^{7}$

This means that the ambiguous student statements are caused by two things. On the one hand, non-Muslim students want to mingle and study AIK with Muslim students and this course is mandatory for every student at UMSU. On the other hand, they have had an ideology that has bound them for a long time. And the doctrine they profess binds and shackles their minds and hearts.

This seems to be a serious problem that must be considered by UMSU's internal stakeholders. Because this has been stated in the book "Guidelines for AIK Al-Islam Education and Muhammadiyah Higher Education Kemuhammadiyahan", one of the problems of learning AIK in PTM is that there is no special approach in PTM that has non-Muslim students. (PP Muhammadiyah Board of Higher Education, 2013). The problems faced by nonMuslim students at UMSU make studying AIK ineffective. As Kahar found in his research at the Muhammadiyah University of Sorong, the implementation of AIK was not running optimally. ${ }^{8}$

To realize the effectiveness of AIK learning for non-Muslim UMSU students, it is necessary to modify the material. As explained by Tobroni that multicultural AIK needs to be

\footnotetext{
${ }^{5}$ Wawancara dengan AHN melalui WhatsApp, pada 11 Agustus 2021.

${ }^{6}$ Wawancara dengan AHN melalui WhatsApp, pada 11 Agustus 2021.

${ }^{7}$ Teguh Prasetyo, "Memperkuat Ideologi Kebangsaan Melalui Perdamaian di Indonesia", pAx Humana

Jurnal Humaniora Yayasan Guna Darma, Vol. II, No.3, (September 2015): 151-163. http:/ / download.garuda.ristekdikti.go.id/article.php?article $=510550 \& v a l=$ 10436\&title=Memperkuat $\% 20$ Ideologi $\% 20$ Kebangsaan $\% 20$ Melalui $\% 20$ Perdamaian $\% 20 \mathrm{di} \% 20$ Indonesia ${ }^{8}$ Muhammad Syahrul Kahar, "Profil Pendidikan Karakter Mahasiswa Non Muslim dalam Implementasi Al-Islam dan Kemuhammadiyahan". Al-Hayat, 2(1), (Juni 2018): 79-80. https:// alhayat.or.id/ index.php/ alhayat/ article/view/21.
} 
organized as a PTM whose majority of students are non-Muslims, who need to be given direction by teaching various universal themes. ${ }^{9}$

In the case of UMSU, although non-Muslim students are minorities, according to the research team, it is necessary to consider teaching AIK, especially the Aqidah-Akhlak and Worship courses, in a softer (simple) way, through "Islamology" material. With Islamology, they study Islam not feeling indoctrinated, but studying Islam academically and rationally. Or, for worship courses in particular, non-Muslim students do not need to be given the same as other Muslim students. Tamrin said that the practice of worship does not need to be taught to non-Muslim students for the benefit. ${ }^{10}$ Next are questions related to the strategies and methods used by lecturers in teaching AIK courses. This item is still related to the previous table data.

Tabel. 3 General Opinions of UMSU Students About AIK Learning Strategies \& Methods

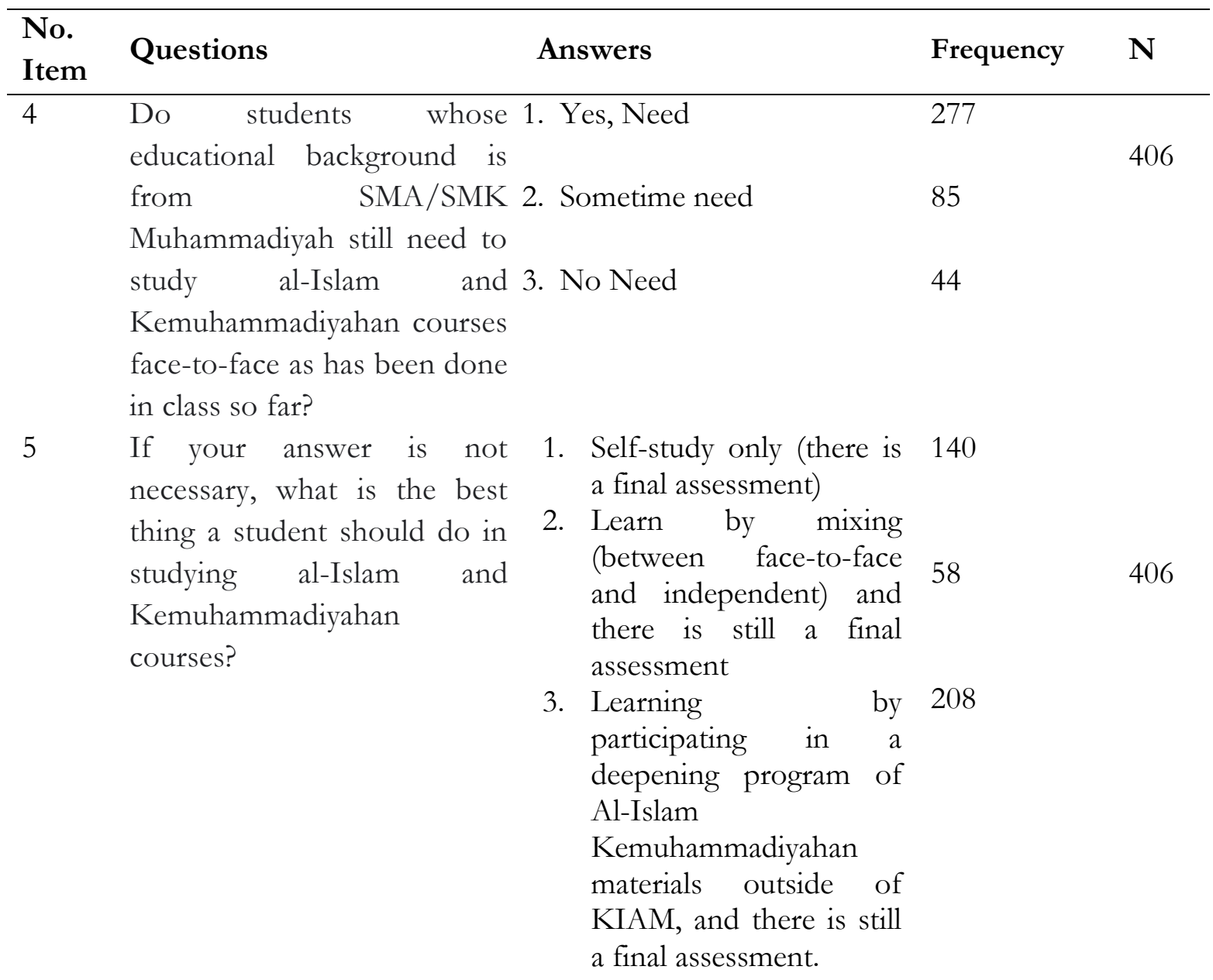

${ }^{9}$ Tobroni, $\quad$ https://umsida.ac.id/aik-multikultural-untuk-ptm-yang-mayoritasnya-mahasiswa-non-

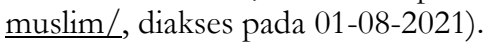

${ }^{10}$ Muhammad Tamrin, "Al-Islam dan Kemuhadiyahan (AIK) Pilar Dakwah Islam Rahmatan Lil Alamin (Studi Pada Perguruan Tinggi Muhammadiyah di NTT)", TA'LIM: Jurnal Studi Pendidikan Islam, 2 (1), 2019, p 6987. 
6 How should teaching al- 1. Not impressed by 117 Islam and Muhammadiyah imposing religious courses be applied at UMSU? doctrine or

Muhammadiyah religious understanding on students

2. It is okay to sometimes impose a doctrine as it already exists and has been running so far.

3. It must be carried out in accordance with so far without considering the religious background and religious understanding of students.

Are the strategies and

1. It's very precise material correct? the lecture method

lecturer do?

2. Don't overwork

90

3. Don't be too 81 monotonous in teaching

4. Everything is correct $\quad 170$

$9 \quad$ Are the learning strategies 1. It fits 221 used by lecturers in 2. Sometimes appropriate 180

Statements of students whose educational background is from SMA/SMK Muhammadiyah still need to study al-Islam and Kemuhammadiyahan courses in a face-toface manner as implemented in class so far. 277 respondents $(68.2 \%)$ stated it was very necessary. 85 respondents $(20.9 \%)$ said it was not necessary, and 44 (10.85) respondents said it was not necessary.

If your answer is not necessary, what is the best thing a student should do in studying al-Islam and Kemuhammadiyahan courses. This question was answered by the respondents as follows. 1) stating that independent learning only (there is still a final assessment) stated by 140 respondents, 2) learning by mixing (between face-to-face and independent) and there is still a final assessment of 58 respondents, and 3) stating that learning by participating in an deepening program on the materials of Al-Islam Kemuhammadiyahan) outside of KIAM, and there is still a final assessment, answered by $208(51.2 \%)$ respondents. This offer might be 
considered to enrich the AIK course development program, towards being more productive, effective, and efficient.

Item 6 questions about how to apply AIK course learning to students. 117 (28.8\%) respondents stated that they should not be impressed by imposing religious doctrines or Muhammadiyah religious ideas on students. 79 (19.5\%) stated that it is okay to sometimes impose doctrine as it already exists and has been running so far, and 150 (36.9\%) respondents stated that it must be carried out according to so far without considering the religious background and religious understanding of students. This means that the majority of respondents continue to state that the AIK learning strategy so far has been sufficient.

This seems also relevant to item number 7 which questions the AIK learning strategies and methods that have been used so far. Respondents who stated that it was very correct were 226 people (55.7\%), who stated that sometimes there were 173 people (42.6\%), and those who stated that they were not correct, only 7 people $(1.7 \%)$.

Questionnaire item 8 is a questionnaire to see the accuracy of the respondent's answers above, the question is presented again if it is answered sometimes or incorrectly, what should the lecturer do? There were 90 students who stated that they should not use the lecture method dominantly using the lecture method, $65(16 \%)$, who stated that they should not do too much work, there were 90 people $(22.2 \%)$, who stated that they should not be too monotonous in teaching, there were 81 people $(19.9 \%)$, and who stated that everything was correct. there were 170 people $(41.9 \%)$.

Questionnaire number 9 still questions about the AIK learning strategies used by lecturers so far. There were 221 respondents $(54.4 \%)$ who stated that it was appropriate, 180 respondents $(44.3 \%)$ stated that it was sometimes appropriate, and only 5 people $(6.1 \%)$ stated that it was not in accordance with the needs of students.

The answers to some of the questions above seem less consistent. However, the answers to items eight and 9 are problems faced by students in the process of learning AIK courses, in many PTMs. This is also a finding from several studies, which state that the learning methods used by lecturers in teaching AIK are still predominantly conventional. ${ }^{11}$ See also Amini ${ }^{12}$, and Pinem. The lecturers still use classical learning methods, rarely use multimedia that can update their knowledge. ${ }^{13}$ The following will explain the needs of UMSU students with non-Muhammadiyah backgrounds for AIK courses.

\footnotetext{
${ }^{11}$ Faridi, Persepsi Mahasiswa Terhadap Matakuliah Al-Islam dan Kemuhammadiyahan (AIK) : Internalisasi Nilai-Nilai AIK Bagi Mahasiswa. Progresiva, 4(1), 2010. 61-70.

${ }^{12}$ Nur Rahma Amini, Implementasi Kurikulum Al-Islam dan Kemuhammadiyahan dalam Meningkatkan Sikap Religiusitas Mahasiswa di Universitas Muhammadiyah Sumatera Utara, Intiqad: Jurnal Agama Dan Pendidikan Islam, 2019, 11(2), 45.

${ }^{13 R i k i}$ Saputra, "Kajian Al-Islam dan Ke-Muhammadiyahan (AIK) Universitas Muhammadiyah Sumatera Barat dalam Perspektif Filsafat Ilmu Ke-Islaman”, MENARA Ilmu. Vol. XIV No.01, 2020, p. 121-129.
} 
Tabel. 4 The Needs of UMSU Students with Non-Muhammadiyah Backgrounds for AIK Learning

\begin{tabular}{|c|c|c|c|c|}
\hline $\begin{array}{l}\text { No. } \\
\text { Item }\end{array}$ & Questions & Answers & Frequency & $\mathbf{N}$ \\
\hline 10 & $\begin{array}{l}\text { For Muslim students who } \\
\text { come from religious beliefs } \\
\text { (organizations) other than } \\
\text { Muhammadiyah, how do you } \\
\text { feel when you study worship } \\
\text { material that is different from } \\
\text { what you studied before? }\end{array}$ & $\begin{array}{l}\text { 1. Very annoyed (because } \\
\text { I feel like I'm being } \\
\text { forced to change the } \\
\text { way I've been practicing } \\
\text { for years). } \\
\text { 2. Sometimes Distracted } \\
\text { (because I find it } \\
\text { difficult to memorize } \\
\text { new prayers, and it is } \\
\text { difficult to leave old } \\
\text { prayers } \\
\text { 3. Undisturbed (because } \\
\text { like it or not to be lived) }\end{array}$ & 125 & 396 \\
\hline
\end{tabular}

Item 10 explains that generally students who come from non-Muhammadiyah religious (organizational) schools state that they are disturbed in learning worship materials. The reasons are: 1) because they feel compelled to change the rituals of worship that have been applied for years, 2) they feel that it is difficult to memorize new prayers. And not a few who do not feel disturbed (because they like it or not, there are 125 respondents $(31.6 \%)$.

However, from an interview conducted with one of the respondents (with the initials $\mathrm{LE})^{14}$, it was revealed that he would try to learn the procedures for worship and prayers taught at UMSU, with the reason that he wanted to be better. The reason why LE was chosen as one of the respondents being interviewed was because the answers to the questionnaire he filled out were consistent and logical from the first question to the end, and were not ambiguous. The following is data on the needs of students with educational backgrounds from Muhammadiyah schools

Tabel. 5 The Needs of UMSU Students with Muhammadiyah Education Background on AIK Learning

\begin{tabular}{lllll}
\hline $\begin{array}{l}\text { No. } \\
\text { Item }\end{array}$ & Questions & Answers & Frequency & N \\
\hline 11 & For Muslim students who have 1. Yes & 131 & \\
& $\begin{array}{l}\text { previously studied at 2. Sometimes } \\
\text { Muhammadiyah schools, do you 3. No }\end{array}$ & 135 & 406 \\
& $\begin{array}{l}\text { think that the al-Islam and } \\
\text { kemuhammadiyahan courses }\end{array}$ & & \\
& $\begin{array}{l}\text { studied for 2, 3, or 4 semesters are } \\
\text { a repetition? }\end{array}$
\end{tabular}

${ }^{14}$ Wawancara dengan LE melalui WhatsApp, pada 11 Agustus 2021. 
12

If your answer is Yes, is it
necessary to re-learn?

1

Yes (but in a

different way or program, but the substance remains the same) 396

2. It's okay (but no 200 longer in the same way and strategy as at school)

3. No (replace with another program)
167 


\begin{tabular}{|c|c|c|c|c|}
\hline & & $\begin{array}{l}\text { are only intended } \\
\text { for majors) tertentu }\end{array}$ & & \\
\hline \multirow[t]{6}{*}{14} & Do you think it is necessary for & 1. Very Necessary & 304 & \\
\hline & the content of Muamalah material & 2. Less necessary & 64 & 406 \\
\hline & (on certain topics) to be adapted & 3. No need & 38 & \\
\hline & to the study program you are & & & \\
\hline & taking? For example: for the & & & \\
\hline & $\begin{array}{l}\text { Faculty of Agriculture, which } \\
\text { discussed the concept of } \\
\text { preserving nature/agriculture } \\
\text { according to Islam. }\end{array}$ & & & \\
\hline \multirow[t]{5}{*}{15} & Is it necessary to group lectures & 1. Very necessary & 128 & \\
\hline & according to the student's religious & 2. It may & 153 & 406 \\
\hline & background, & necessary & & \\
\hline & $\begin{array}{ll}\text { understanding, } & \text { educational } \\
\text { background } & \text { between }\end{array}$ & 3. No need & 125 & \\
\hline & $\begin{array}{l}\text { Muhammadiyah and non- } \\
\text { Muhammadiyah? }\end{array}$ & & & \\
\hline \multirow[t]{3}{*}{16} & All courses (Al-Islam and & 1. Very Necessary & 307 & \\
\hline & Muhammadiyah) need to be taught & 2. Less necessary & 76 & 406 \\
\hline & $\begin{array}{l}\text { in a way that is appropriate to the } \\
\text { student's religious background. }\end{array}$ & 3. No need & 23 & \\
\hline \multirow[t]{3}{*}{17} & All courses (Al-Islam and & 1. Very Necessary & 235 & \\
\hline & Muhammadiyah) need to be taught & 2. Less necessary & 70 & 406 \\
\hline & $\begin{array}{l}\text { in a way that fits the student's } \\
\text { educational background? }\end{array}$ & 3. No need & 101 & \\
\hline \multirow[t]{3}{*}{18} & All courses (Al-Islam and & 1. Very Necessary & 240 & \\
\hline & Muhammadivah) need to be taught & 2. Less necessary & 72 & 406 \\
\hline & $\begin{array}{l}\text { in a way that fits the student's } \\
\text { religious background? }\end{array}$ & 3. No need & 94 & \\
\hline
\end{tabular}

Item 14 explains that most students still state that studying muamalah courses remains as it is, because it is considered to still suit their needs. Only a few said it was not appropriate. The respondent's statement on item 14 becomes less valid. Because in item 15, respondents stated that the Muamalah material (on certain topics) was adjusted to the study program taken by students. For example: for the Faculty of Agriculture, which discussed the concept of preserving nature/agriculture according to Islam. 304 respondents (74.9\%) stated strongly agree..

Item 16 explains the need to group lectures according to the student's religious background, religious understanding, educational background between Muhammadiyah and non-Muhammadiyah. 128 respondents said it was very necessary, 153 said it might be necessary. This means that 128 respondents plus half stated that it might be necessary (77) people, so that there were 205 people who answered that it was necessary $(50.5 \%)$. Meanwhile, those who stated it was not necessary were 125 people plus 76, bringing the total to $201(49.5 \%)$. So, almost fifty-fifty (which states necessary, and not necessary).

Item 17 reveals data on strategies for studying AIK courses. Respondents who answered that it was very necessary to study AIK according to the religious background of 
students as many as 307 respondents $(75.6 \%)$ answered very necessary, 76 people $(18.7 \%)$ answered less necessary, and only 23 people (5.7\%) answered not necessary. The same is true for item 17. Respondents stated that AIK courses need to be taught in a way that is in accordance with the student's educational background. 235 respondents (57.9\%) stated it was very necessary. And item 18 states that AIK courses need to be taught in a way that is in accordance with the students' religious background. 240 respondents $(50.2 \%)$ who stated it was very necessary.

The six questionnaire items above confirm that students generally want that studying AIK courses needs to use the right strategy, namely by grouping students according to the study program they take, according to their religious background, according to their educational background, and adapted to the religious understanding of students.

Student needs for AIK learning strategies at UMSU seem to have referred to considering the results of research conducted by Santoso which stated that AIK learning at PTMA with heterogeneous students should refer to multicultural AIK learning (PP Diktilitbang Muhammadiyah), that AIK learning techniques are separated between ( Islamic and non-Muslim students), for AIK I. AIK II, AIK III, and AIK IV (Islamic Ethics, and Kemuhammadiyahan Studies, Islam and Science and Technology) are taught according to their respective study programs. ${ }^{15}$ When applied to AIK courses at UMSU, AIK learning can be described as in the following table.

Tabel.7 UMSU Student AIK Learning Strategy

\begin{tabular}{|c|c|c|c|}
\hline No. & Courses AIK & Student Criteria & Strategy/Learning Model \\
\hline 1 & Aqidah/Akhlak & Non-muslim & $\begin{array}{l}\text { Study Islamology \& separate } \\
\text { with Muslims }\end{array}$ \\
\hline \multirow{3}{*}{2} & \multirow{3}{*}{ Ibadah } & Muslim & $\begin{array}{l}\text { Grouped between } \\
\text { Muhammadiyah and non- } \\
\text { Muhammadiyah }\end{array}$ \\
\hline & & Non-muslim & $\begin{array}{l}\text { Study Islamology \& separate } \\
\text { with Muslims }\end{array}$ \\
\hline & & Muslim & $\begin{array}{l}\text { Grouped between } \\
\text { Muhammadiyah and non- } \\
\text { Muhammadiyah }\end{array}$ \\
\hline 3 & Muamalah & $\begin{array}{l}\text { Non-muslim } \\
\text { Muslim }\end{array}$ & According to Study Program \\
\hline 4 & Kemubammadiyahan & $\begin{array}{l}\text { Non-muslim } \\
\text { Muslim }\end{array}$ & Contextual and conditional \\
\hline
\end{tabular}

${ }^{15}$ Budi Santoso dan Muhammad Muzakki, "Pembelajaran AIK Multikultural di Universitas Pendidikan Muhammadiyah Sorong". Jurnal SABDA (Sarana Dakwab), 2020, 1(1), https://unimuda.ejournal.id/PAI/article/view/436. 


\section{CONCLUSION}

The results of the discussion of the data found in the field show that the map of the needs of UMSU students for Al-Islam and Kemubammadiyahan courses is as follows. First, that the current $A I K$ courses given to UMSU students are not in accordance with the student's needs. This can be seen from the data which shows that in the learning process.

Second, the map of the needs of UMSU students for AIK courses is as follows. 1) Students who do not have a religious understanding background from the Muhammadiyah organization consisting of $76.8 \%$ (92 people) of 396 Muslim respondents stated that giving Worship courses in particular does not make it a doctrine and coercion, but must pay attention to the background of religious understanding they have previously embraced. This means that the delivery of material is carried out by means of maui'atul hasanah and mujdah. 2) Non-Muslim students generally state that Worship courses are not taught in the form of doctrine as given to Muslim students, but must consider their religious background. And the AIK courses should be taught in the form of Islamology courses. 3) Students with educational backgrounds from Muhammadiyah tend to want AIK courses to be packaged with other programs. Or by mixing (mixing) face-to-face in class with more interesting programs, and not just face-to-face routines in class. 4) Most of the respondents stated that learning strategies and methods need to be adapted to the appropriate needs of students.

\section{ACKNOWLEDGMENT}

This research was fully funded by the RAB of the Muhammadiyah University of North Sumatra which was managed by LPPM UMSU. Therefore, it is appropriate and appropriate for this research team to express their deepest gratitude to the Chancellor of UMSU, who has issued a policy for UMSU's internal research funding. Hopefully the funding provided is useful in scientific development, and the results of this research can be donated to institutional development.

\section{REFERENCES}

Amini, Nur Rahmah. "Implementasi Kurikulum Al-Islam dan Kemuhammadiyahan dalam Meningkatkan Sikap Religiusitas Mahasiswa di Universitas Muhammadiyah Sumatera Utara". Intiqad: Jurnal Agama Dan Pendidikan Islam, 11(2), (Desember 2019): 359-372. DOI: http://dx.doi.org/10.30596\%2Fintiqad.v11i2.3265

Faridi. (2010). "Persepsi Mahasiswa Terhadap Matakuliah Al-Islam dan Kemuhammadiyahan (AIK) : Internalisasi Nilai-Nilai AIK Bagi Mahasiswa". Progresiva, 4(1), (Agustus 2010): 61-70. https://www.neliti.com/id/publications/220737/persepsi-mahasiswa-terhadapmata-kuliah-al-islam-dan-kemuhammadiyahan-aik-intern\#id-section-content.

Kahar, Muhammad Syahrul. "Profil Pendidikan Karakter Mahasiswa Non Muslim dalam Implementasi Al-Islam dan Kemuhammadiyahan". Al-Hayat, 2(1), (Juni 2018): 79-80. https://alhayat.or.id/index.php/alhayat/article/view/21.

PP. Muhammadiyah, T. P. P. A.-I. dan K. M. P. T. P. Buku Pedoman Pendidikan Al-Islam dan Kemuhammadiyaban Perguruan Tinggi Muhammadiyah. Yogyakarta: Majelis Pendidikan Tinggi Muhammadiyah PP Muhammadiyah. (2013).

Nurzannah. "Analisis Perilaku Keagamaan Mahasiswa Universitas Muhammadiyah Sumatera 
Utara (Studi Kasus Pada Mahasiswa Fisipol Semester V TA. 2016-2017)". Jurnal HIJRI Jurnal Manajemen Pendidikan Dan Keislaman, 6(1), Januari-Juni 2017). 150-165. http://jurnal.uinsu.ac.id/index.php/hijri/article/view/1102/874

Pinem, Rasta Kurniawati br. "Metode Pembelajaran Al-Islam Dan Kemuhammadiyahan Di Universitas Muhammadiyah Sumatera Utara". Intiqad: Jurnal Agama Dan Pendidikan Islam, 11(2), (Desember 2019).

373-395.

DOI: http://dx.doi.org/10.30596\%2Fintiqad.v11i2.3753

Prasetyo, Teguh. "Memperkuat Ideologi Kebangsaan Melalui Perdamaian di Indonesia". $p A x$ Humana Jurnal Humaniora Yayasan Guna Darma. Vol. II, No.3, (September 2015): 151 163. http://download.garuda.ristekdikti.go.id/article.php?article $=510550 \& v a l=$ $10436 \&$ title $=$

Memperkuat\%20Ideologi $\% 20$ Kebangsaan\%20Melalui \%20Perdamaian\%20di\%20Indon esia

Santoso, Budi., dan Muhammad Muzakki. (2020). Pembelajaran AIK Multikultural di Universitas Pendidikan Muhammadiyah Sorong. Jurnal SABDA (Sarana Dakwah). 1(1). https://unimuda.e-journal.id/PAI/article/view/436

Saputra, Riki. (2020). Kajian Al-Islam Dan Ke-Muhammadiyahan (AIK) Universitas Muhammadiyah Sumatera Barat Dalam Perspektif Filsafat Ilmu Ke-Islaman. MENARA Ilmu. Vol. XIV No.01. p. 121-129. DOI: https://doi.org/10.31869/mi.v14i1.1869

Tamrin, Muhammad. "Al-Islam Dan Kemuhadiyahan (AIK) Pilar Dakwah Islam Rahmatan Lil Alamin (Studi Pada Perguruan Tinggi Muhammadiyah di NTT)". TA'LIM: Jurnal Studi Pendidikan Islam. 2 (1), (2019). p p 69-87. http://ejurnal.unisda.ac.id/index.php/talim/article/view/1299

Tobroni, AIK Multikultural Untuk PTM Yang Mayoritasnya Mahasiswa Non Muslim.https:// umsida.ac.id/aik-multikultural-untuk-ptm-yang-mayoritasnya-mahasiswa-nonmuslim/,01-08-2021 